\title{
The Nature and Functions of Loci in Agricola's De Inuentione Dialectica
}

\author{
Eddo Rigotti
}

Published online: 16 October 2013

(C) Springer Science+Business Media Dordrecht 2013

\begin{abstract}
This paper aims to single out and to highlight the fundamental tenets of Agricola's De inuentione dialectica. After the structure of the volume, its theoretical perspective and its educational concern are illustrated, Agricola's understanding of the fundamental notion of locus is expounded. In this relation his particular use of the medieval term habitudo and the exclusion of maxims, which had been the main concern of the Medieval doctrine of loci, show a certain distance from the Medieval tradition. Several innovative and constructive contributions of Agricola's work are stressed, in particular the elaboration of a new taxonomy of loci and the discovery of the relevant role played by loci not only in argumentation but also in exposition and in explanation. In this way, loci acquire the status of intentiones secundae, i.e. of meta-categorical concepts which govern the connections ensuring textual congruity. A reading of this text in the light of contemporary argumentation theory reveals a surprising topicality and richness of concrete contributions in some dialectical and rhetorical domains, like argument schemes, topical potential, and presentational techniques.
\end{abstract}

Keywords Argument schemes · Emotions · Exposition · Habitudo $\cdot$ Loci · Maxims

\section{Introduction}

The purpose of this paper is to bring to light the fundamental tenets of a text that has undoubtedly represented a relevant step in the evolution of argumentation studies:

E. Rigotti $(\bowtie)$

Institute of Argumentation, Linguistics and Semiotics, USI-University of Lugano, Via G. Buffi 13, 6904 Lugano, Switzerland

e-mail: eddo.rigotti@usi.ch 
Agricola's De inuentione dialectica. ${ }^{1}$ My reading is based on two editions, which both appeared in Köln in $1539^{2}$ and in $1557^{3}$ respectively and which both declare to present a version of Agricola's text according to the autograph manuscript of Agricola recently recovered by Alardus Aemstelredamus. Quotations and references to the original adopt the 1539 edition and the critical edition of this text without commentaries offered by Mundt (1992). ${ }^{4}$

After the structure of the work, its theoretical perspective and its educational purposes are outlined, Agricola's approach to the fundamental notion of locus is illustrated. The divergent use of the term habitudo by Agricola and by Medieval scholars and the removal from dialectical invention of maxims, which had been the central theoretical construct of the Medieval doctrine of loci, will allow us to

\begin{abstract}
${ }^{1}$ Born near to Groningen at Baflo (natione Friso) (February 17, 1444, see the discussion over the date of birth in Akkerman 2012: 10 and ff.), Agricola was a "Dutch" scholar, humanist, and musician. He is known to us mainly as the author of the book we are now considering. The original Dutch name Roelof Huismann was translated by himself into Rodolphus Agricola. Educated first in St. Maartens school in Groningen, he then matriculated at the university of Erfurt and then at the university of Louvain, where he graduated as magister artium (distinguishing himself for the purity of his Latin and his skill in disputation). He concentrated his studies particularly on Cicero and Quintilian. He was endowed with an extraordinary multilingualism (see in this regard the Commentarii about the life of Agricola, written by Johann von Plieningen for his brother, in Akkerman 2012, p. 74), both in ancient and in modern languages: to his ever-growing language repertoire he added French and Greek during his university years and Hebrew in his late years. He could also speak fluently and elegantly the Italian and the German vernaculars.
\end{abstract}

After living for a time in Paris, where he worked with Heynlin von Stein, - a classics specialist-he went, in around 1464, in Italy, where he associated with humanist masters and statesmen. In the years 1468-1475 he studied at the University of Pavia and later went to Ferrara, where he attended lectures on the Greek language of the famous Theodorus Gaza (c. 1400-1475), also called by the epithet Thessalonicensis, a Greek humanist and translator of Aristotle, one of the Greek scholars who were the leaders of the revival of Greek culture in the 15th century. Here Agricola wholly devoted himself to the study of classical texts. He won renown for the elegance of his Latin style and his knowledge of philosophy. Also while in Ferrara he was formally employed as the organist to the ducal chapel, which was one of the most opulent musical establishments in Europe. He held that post until 1477, after which, having visited Rome, he definitively turned to his native country in 1481. Once in "Germany" again, he spent time in Dilligen. It was in Dilligen in 1479 that Agricola finished De inuentione dialectica. In 1482, on the invitation of Johann von Dalberg, bishop of Worms, with whom he had become friendly while in Italy at the university of Pavia, he accepted a professorship at the University of Heidelberg and for 3 years lectured there and at Worms on the Greek literature. In 1485 Agricola accompanied Dalberg, who was sent as an ambassador to Innocent III the new elected Pope in Rome, but was struck gravely ill on the journey back to home. He died in the autumn of the same year "mente in Deum porrectissima". In the cultural history of Europe of the late fifteenth century, he is considered as the father of northern European humanism (Vasoli, 1968). For more details on his life and on his works see Akkerman (2012) and Mack (1993, 117-129).

${ }^{2}$ Rodolphi Agricolae Phrisii de inuentione dialectica libri omnes et integri et recogniti, qui iam olim quidem in publicum prodierunt, sed trunci ac mutili nec minus item deprauati, nunc demum ad autographi exemplaris fidem per Alardum Aemstelredamum accuratius emendati, et additis annotationibus illustrati (...) Coloniae Ioannes Gymnicus excudebat Anno a Christo nato M. D. XXXIX.

${ }^{3}$ Rodolphi Agricolae Phrisii de inuentione dialectica libri omnes integri et recogniti iuxta autographi, nuper D. Alardi Aemstelredami opera in lucem educti fidem, atque doctissimis scholiis illustrati, Ioannis Phrissem, Alardi Aemstelredami, Reinardi Hadamarii. Quorum scholia exactissimo iudicio contulit ac congessit Ioannes Nouiomagus. Coloniae Anno M. D. LVII.

4 The references to Agricola's text are structured as follows: the roman numeral indicates the book; the two following numbers, divided by the colon, indicate the chapter and the line in Mundt's edition respectively; after the slash, the correspondent page in Köln edition of 1539 is also provided. 
consider and evaluate the polemical position of Agricola towards the Medieval tradition. Several innovative aspects of Agricola's contribution are expounded: the elaboration of a new taxonomy of loci, a different, often more precise and useful, characterization of loci, in particular of the locus from definition, and the discovery of the relevant role played by loci not only in argumentation but also in exposition. Eventually we show that in the light of contemporary argumentation theory this text is found to be surprisingly topical and rich in concrete contributions, especially in some dialectical and rhetorical domains, like argument schemes, topical potential, and presentational techniques.

\section{Three Books Focusing on Loci}

In the three books on dialectical invention (Agricola 1539), the attitude of Rodolphus Agricola towards tradition is inspired both by continuity and innovation.

In line with the late-ancient and medieval tradition, his main focus is centered on loci: the whole first (longest) book of the treatise is devoted to the investigation of the nature of loci, which are defined in general and described in detail, often by adopting punctual semantic analyses. The second book specifies the uses of loci and, eventually, the third mainly focuses on the rhetorical effectiveness of arguments and loci are again considered in this perspective.

In the Prooemium (I, 1: 11/p. 1) the three tasks ascribed by ancient rhetoric to human discourse (oratio) are mentioned: informing and teaching (ut doceat $t^{5}$ ), moving (ut moveat), pleasing or entertaining (ut delectet). Discourse can inform without moving or entertaining, but it can neither move nor entertain without informing. Therefore information proves to be its essential, ever present, function. Depending on the speaker's intention, this informative function may alternatively assume two forms: sometimes we let the hearer know something simply to make him understand it, thus fulfilling a function of exposition, sometimes we let somebody know something in order to establish a belief in what is said, thus performing an argumentation (I, 1: 30-31/p. 2). The author defines exposition as a discourse that only manifests the mind (mentem "communicative intention") of the speaker, without activating anything that aims at arousing trust in the hearer. Argumentation is instead defined as a discourse through which somebody tries to build trust in the thing he is speaking about. Now, as what is uncertain cannot as such support itself, we must infer trustworthiness moving from other, better known and more familiar things. These things are arguments or, following Cicero, reasonable devices or inventions (probabile inventum) through which some uncertain things are given trustworthiness (I, 1: 34-38/p. 2). Since not everyone is able to promptly identify such devices, in Agricola's opinion, the identification of loci, understood as some seats or places whence arguments can be drawn, represents a particularly useful educational endeavor: as possible beneficiaries, he especially mentions people engaged in political, legal, educational, moral and religious discourse and stresses

\footnotetext{
5 The Latin word doceo means in general contexts "to let know" or "to inform", and in the educational contexts "to teach".
} 
that the system of loci does not simply educate the mouth, by offering a rhetorical enrichment (copia dicendi), but it also ensures wisdom of judgment (prouidentia) in consulting and in pondering decisions (I, 1: 64-69/pp. 2-3).

Following Cicero (Topica, 6, in Reinhardt ed. 2003) and Boethius (De differentiis topicis, 1173B, in Stump ed. 1978), he distinguishes, within dialectic-understood, according to the usual definition, as the art of arguing (ars disserendi) (II, 2: 20/p. 191) - a heuristic and an evaluative component: the latter one is identified with Aristotelian Analytics and De sophisticis elenchis (iudicii pars, cui omnis de modis figurisque syllogismorum praeceptio et cautio omnis captiosarum argumentationum, quas fallacias dixere, subseruit) (I, 2: 86-88/p. 9) and is not the proper subject of Agricola's opus which is wholly devoted to the former component (Sed nos de priore illa parte quae ad inueniendum pertinet loquemur) (I, 2: 89-90/p. 9). So, separating the topical component from the normative one, and thus overthrowing the logically oriented Medieval tradition started by Boethius, Agricola recovers from Roman rhetoric (in particular from Cicero and Quintilian) an approach ascribing to rhetoric a relevant role towards dialectic, where dialectic, reduced to inuentio, appears to be mainly justified because it is useful for rhetoric. Therefore the program of Agricola's dialectic, though recovering a unitary perspective comprising rhetoric and dialectic and thus, somehow, anticipating the strategic maneuvering perspective adopted by the extended version of Pragma-Dialectics (van Eemeren and Houtlosser 2002; van Eemeren 2010) could hardly be compared with it, because, being exclusively committed to the finding (discovering) of arguments, its dialectical approach postpones the commitment of ensuring argumentation validity.

Here, a clarification is, however, useful. The fact that the evaluative component is not given a central position in the design of the work did not at all condition Agricola's work in its actual realization, since a strong critical commitment frequently emerges from his pages. ${ }^{6}$ Consequently the impression prevails that dialectic and rhetoric are, in actu exercito, correctly reconciled. Moreover, at the beginning of the second book the specific role of the normative (logical) component of dialectic is concisely, but clearly highlighted; "It is ignored even by very learned people that no argumentation represents a necessary inference simply because it is drawn from species or genus or any other locus, but that it obtains cogency only when there is such a connection between things that can be formulated as a syllogism or any other approved logical form, by means of which we can conclude that the connected things are necessarily connected" ${ }^{7}$ (II, 1: 32-40/p. 179).

\footnotetext{
${ }^{6}$ See, on this point, the remarks made by Mack (1993: 168).

7 "Nec intelligunt doctissimi uiri (sic enim modestissimum mihi est ipsos uocare) nullam argumentationem, quia a specie, uel genere, uel quouis aliorum locorum ducatur, necessario cohaerere: quoniam ex omnibus istis ineptae et minime cohaerentes duci queant, sed tum demum cohaerere argumentationem, cum est ea rerum inter se conditio, ut possint coniici in syllogismi uel aliam quampiam formam argumentandi probatam, per quam cohaerentes inter se res, et necessaario connexas esse colligatur".

Here and in other passages of the paper, Agricola's Latin text is rendered through my own English translation. The German translation of Mundt (1992) was also considered. The original Latin text, however, is always provided.
} 
But let us come back to the interpretation of the system of loci (ratio locorum) that represents the main concern of Agricola's work. His awareness of the ontological nature of $\operatorname{loci}^{8}$ (see I, 2: 96-106/p. 9) is absolutely evident: "All things that are said in favor or against the standpoint are bound together and are (so to say) connected by a sort of solidarity of nature".?

The endless variety of things and of their distinctive features cannot be embraced by any discourse nor by any mind. "Inherent to all things, there is although a common habitudo and all things tend to a similarity of nature: like the fact that all things have their own substance, all things originate from some causes and, in turn, cause something; and thus the most intelligent men have drawn from that enormous variety of things these common headings $\left(\right.$ capita $\left.^{10}\right)$ like substance, cause, result, and the other headings, which we shall consider in the following" ${ }^{11}$ (I, 2: 91-93/p. 9). A locus is nothing else but a certain aspect characterizing the thing (rei nota), orienting us in identifying what, in relation to each standpoint, can provide acceptability $^{12}$ (ibid.).

But how should the term habitudo be interpreted? This term had played a central role in the Medieval doctrine of loci, where it was understood as the ontological relationship (like cause to effect, definition to defined, means to end etc.) binding the state of affairs exploited as argument to the state of affairs constituting the standpoint (Rigotti 2008). In other words, every locus was understood as a particular type of habitudo in the sense of "se habere ad"13 ("to be related to"). It is rather

\footnotetext{
8 Agricola's realistic position and its connection with the Medieval scholastic doctrines of universals are investigated by Nauta (2012).

9 "omnia quae uel pro re quaque uel contra dicuntur, cohaerere, et esse cum ea quadam (ut ita dicam) naturae societate coniuncta."

${ }^{10}$ The term is used by Cicero (Topica 39) with a different meaning in relation to the argument from genus, which should not necessarily be identified with the ultimate genus (non erit necesse usque a capite arcessere), but simply with the immediately relevant genus.

11 "Inest tamen omnibus (tametsi suis quaeque discreta sint notis) communis quaedam habitudo, et cuncta ad naturae tendunt similitudinem, ut quod est omnibus substantia quaedam sua, omnia ex aliquibus oriuntur causis; omnia aliquid efficiunt. Ingeniosissimi itaque uirorum, ex effusa illa rerum varietate, communia ista capita: uelut substantiam, causam, euentum, quaeque reliqua mox dicemus, excerpsere, uelut cum ad considerandam rem quampiam animum aduertissemus, sequentes ista: statim per omnem rei naturam et partes, perque omnia consentanea et dissidentia iremus, et duceremus inde argumentum propositis rebus accomodatum."

12 "Non ergo aliud est locus, quam communis quaedam rei nota, cuius admonitu, quid in quaque re probabile fit, potest inueniri”.

13 The following passages of Peter of Spain (see Bochenski ed. 1947), Abelard (see De Rijk ed. 1970) and Buridan (2001) do clearly highlight the notion of habitudo:

"Locus a causa efficiente est habitudo ipsius ad suum effectum" ("The locus from efficient cause is the relation of the thing to its effect") (Petri Hispani Summulae logicales, 5.24);

"Est autem locus-differentia ea res in cuius habitudine ad aliam firmitas consecutionis consistit." "Locus-differentia is the thing in whose relation to another thing the solidity of the inference is created") (Abaelardi De dialectica, 263);.

"Locus-differentia maximae est termini ex quibus constituitur maxima et ex quorum habitudine ad invicem maxima habet notitiam et veritatem. Verbi gratia, cum haec propositio 'Quidquid vere affirmatur de genere vere affirmatur de specie' sit locus maxima, isti termini 'species' et 'genus' sunt locusdifferentia maximae: ex habitudine enim speciei ad suum genus maxima habet veritatem et efficaciam" (Buridani Summulae de dialectica 6.2.2). ("Locus-differentia maximae are the terms of which the maxim consists and from whose mutual relation the maxim draws recognition and truthfulness. For instance, if
} 
clear that in Agricola's text this term does not refer to the relational nature of loci, but to the analogous functional configuration which is shared, due to a solidarity of nature, by all things. ${ }^{14}$ Such habitudo is identified with the net of ontological roles played in different connections by all entities: all things have their own substance, all things originate from some causes and, in turn, cause something, all events take place in a certain time and so on. Curiously, though clearly misunderstanding the medieval notion of habitudo and reading it as the nominalization of se habere" (to be in a certain way) and not of "se habere $a d$ " (to be in a certain relation to), Agricola's conception of loci is substantially compatible with the notion of loci elaborated by the medieval scholars. In fact, in the descriptions offered by Agricola, the headings the loci are identified with are relational in nature: the definition versus the defined, the time and the place versus the event, the efficient cause versus the effect and so on. Nonetheless, Agricola focuses on another relational dimension of loci: they are headings (capita), to be understood as the semantic nodes building a sort of conceptual network which maps reality.

\section{The Removal of Maxims}

There are aspects for which Agricola distances himself more decidedly from the Medieval tradition. In general, a rather polemical attitude towards all medieval scholars is evident. They are cumulatively referred to as "qui post Boethium scripserunt" (see, in particular, I, 3: 152/p. 18 and I, 29: 29-30/p. 175). The renowned philosopher and theologian John Duns Scotus ${ }^{15}$ is mentioned with the formula "secta Scoti" (Agricola 1539, p. 41). ${ }^{16}$ The medieval terminology is largely abandoned or even misunderstood (see above for habitudo). For important respects, his criticisms also involve Boethius from whom the Medieval tradition originates. The classification (diuisio) of loci is partially modified and, more importantly, the mediating role of maxims (maximae propositiones) is ignored. Now, as maxims are the inferential connections generated by the $\operatorname{loci}^{17}$ on which the actual arguments

\section{Footnote 13 continued}

the proposition 'anything that is truthfully affirmed of the genus is truthfully affirmed of the species too' is the maxim, the terms 'species' and 'genus' are the locus-differentia maximae: as a matter of fact, this maxim has validity and effectiveness on the basis of the relation between the species and its genus").

Interestingly, while the first passage only underlines the relational nature of locus, the second also focuses on the inferential strength ensured by locus to maxim and the third, moreover, ascribes to locus the communicative potential of maxim.

14 The German translation by Mundt suggests “äußere Gestalt” as translation of the term habitudo.

15 John Duns Scotus (1265/66-1308) was one of the most influential philosophers and theologians of the of the thirteenth and fourteenth centuries. His brilliant thought earned him the nickname "the Subtle Doctor". Topics like the semantics of religious language, the problem of universals, the nature of human freedom were innovatively investigated by him. For a general overview of his work and his life see Gilson (1952).

16 The pages from 37 to 41 of the 1539 edition of De inuentione dialectica, containing Agricola's reflections about "Singulares aliquot de uniuersalibus quaestiones", are omitted in Mundt's edition.

17 The role played by maxims in the inferential organization of arguments is expounded more in detail in Rigotti and Greco Morasso (2010). 
build, loci are directly bound to actual arguments. In the end of the first book (I, 29: 29-34/p. 175-176) our author tries to justify the absence of maxims in his system of topics. He reminds that "Boethius and those who wrote after him (quique post eum scripserunt) added to each locus, to adopt a usual expression, a certain Maxim, i.e. a statement, comprising in a proposition many aspects, to which undoubted trust is paid, like Of whatever the definition is said, the defined is also said or Of whatever the species is said, the genus is said too". ${ }^{18}$ Now, the author decided to ignore maxims not because, in his opinion, neither Aristotle nor Cicero had considered them, ${ }^{19}$ but because he thought they were simply useless for several reasons.

Firstly, Agricola argues, maxims can be construed only in relation to those loci which provide necessary arguments, but they do not fit (parum conveniet) for loci providing probable arguments, which are the majority (I, 29: 36-39/p. 176).

Secondly, there are many such loci in which these maxims cannot be comprised in any defined and sufficiently convenient form (in nullam certam et satis conuenientem formam concludi hae maximae possint) (I, 29: 39-40/p. 176). In Agricola's opinion, sometimes Boethius appears to be at pain while trying to assign to any locus its own maxim (dum cuilibet loco maximam suam reddere cupit) so that, while the locus is, as a rule, very widely extended, the maxim often receives a very narrow scope (I, 29: 40-43/p. 176). Several examples are given, approximately rendering Boethius' text (cf. De differentiis topicis 1189C, in Stump ed. 1978) in relation to the loci from efficient cause (Quorum efficientia naturalia sunt, eorum effecta sunt naturalia-If the causes are natural, the effects are natural), and in relation to the locus from the matter (ibid. 1189D) (Cuius materia deest, et id quod ex ea efficitur deest-If the matter lacks, the thing made of this matter lacks too) and others (I, 29: 43-48/p. 176). In my opinion, this criticism depends rather evidently on an imprecise interpretation of Boethius' text: Agricola interprets maxims as rules bijectively corresponding to loci: cuilibet loco maximam suam reddere cupit. Even though Boethius' text might suggest this interpretation because, in general, it pairs up one maxim with one locus differentia, it also manifests his awareness that maxims outnumber loci differentiae: "Atque ideo pauciores esse deprehenduntur hi loci qui in differentiis positi sunt quam propositiones ipsae quarum sunt differentiae" (1186B) and in several cases more than one maxim is given in relation to one locus differentia (see 1188D-1189A, where, for the locus a partibus, two maxims are provided). Therefore, between loci differentiae and maxims, Boethius, and even more explicitly the Medieval scholars, ${ }^{20}$ establish an injective relation: one or more maxims, yet, in general, several maxims correspond to one locus, while only one locus corresponds to each maxim. In other words, each maxim

\footnotetext{
18 "Boëtium, quique post eum scripserunt de locis, singulis locis addidisse quandam (ut uulgo loquimur) maximam, id est, pronunciatum quoddam, una sententia multa complexum, cui indubitata sit fides: Ut, de quocunque definitio dicitur, de eo definitum. De quocunque species, de eo genus."

19 While this is the case for Cicero, it is not indeed the case for Aristotle who, though not specifying explicitly the notion of maxim, covers with the term "topoi" both numerous maxim-like rules (Braet 2005; Rigotti 2008).

20 In Abelard's Dialectica (264, in De Rijk ed. 1970) loci (maximarum propositionum differentiae) are said to be fewer (pauciores) than maxims, because "eiusdem differentiae multae maximae propositiones esse possunt" (the same locus differentia can have many maxims).
} 
focuses on one of the inferential implications of the locus and therefore does not exhaust the argumentative potential of the locus. This is the reason why, while the locus is more widely extended, the maxim shows to have a much narrower scope.

The third decisive reason for considering maxims as useless, is that, in Agricola's opinion, all in all, people who have been thoroughly taught the nature of loci do not need maxims, as they spontaneously show themselves to their mind; and, if it is not the case, these people do not deserve to be taught the loci ${ }^{21}$ (I, 29: 53-61/p. 176). In other words, studying maxims is useless because they spontaneously spring from a good awareness of loci.

I feel committed to concisely evaluate the arguments brought by Agricola. The three justifications for the removal of maxims from dialectical invention indeed lack the due cogency: the first one is not at all highlighted nor, all the less, argued for; the second and the third justifications are at least partially incompatible as the second emphasizes the difficulty to assign to the locus its own maxim and the third pretends that maxims spontaneously spring from a good awareness of loci. Moreover, the second is based on a premise (the bijective nature of the relation binding maxims to loci) contradicting not only the interpretation of maxims by Boethius and the Medieval scholars, but also the significant evidences brought by them. Eventually, while the first and the second reasons criticize maxims as theoretical constructs, the third one, which is possibly the most important in the general design of the work, questions the educational and not the theoretical relevance of their study.

In fact, the removal of maxims from the system of loci might be explained by the prevailingly non-theoretical, but practical and educational purpose of this work, which is consistent with the focus on inuentio, already declared in the title, but it is maybe also bound to the author's lack of interest in and commitment to the study of the inferential configuration of arguments. Besides, the inferential configuration of arguments could force him to reconsider the contributions of the Medieval scholars, who, in his eyes, were guilty of an excessive and useless formalism ${ }^{22}$ and, above all, of largely ignoring the relevance of rhetoric.

However, the unquestionable presence of a practical, educational concern in the design of the work should not prevent us from seizing those innovative, critical and theoretical, contributions that are offered in all three books.

\footnotetext{
21 "Adde, quod si quis exacte et penitus cognitam habuerit locorum naturam, nihil erunt ei opus hae maximae, quoniam ultro fere in animum incurrunt, et apertiores sunt quam ut sint discendae. At si quis tam prorsus expers ingenii sit tamque à communi sensu rerum abhorrens, ut apertissima illa propemodum per se nota docendus sit, illi ego nihilo magis, quae de locis praecipiuntur, profutura crediderim, quàm Cimmeriis (quos perpetua nebularum caligine opertos tradunt poëtae) ea, quae de positione siderum deque ipsorum figuris motuque traduntur."

22 In the third book, the excessive use of formal notions and procedures is also identified with the cause of the removal of moral philosophy from education (III, 14: 35-39/pp. 440-441). Syllogistic doctrine is not rejected but limited to the very initial phase of educational path within the school environment (III, 14: 50-53/p. 441).
} 


\section{Innovative Aspects}

In order to better characterize Agricola's contribution, I focus now on some innovative aspects of his doctrine, namely his critical attitude towards tradition, his treatment of loci, and the distinction between argumentation and exposition.

\subsection{Critical Attitude Towards Tradition}

His autonomous, correctly critical, attitude towards the authorities of tradition (even those authorities whom he in general acknowledges and confirms) is often stressed and, even though the contributions by Aristotle, Cicero, Quintilian, Themistius and Boethius are mentioned and brought out, a number of criticisms are addressed to each of them.

In particular, regarding Aristotle, Agricola's judgment is inspired by esteem and admiration, but he avoids any "ipse dixit" devotion: "Ego Aristotelem summo ingenio, doctrina ... summum quidem hominem, sed hominem tamen fuisse puto" (I, 3: 50-53/p. 15) (I believe that Aristotle was a man of the highest intelligence, culture ... a man of the highest level, but that he was a man). In other words, Aristotle was one whom something could escape, so that this could be discovered by somebody else (aliis post se invenienda reliquerit) (I, 3: 53-55/p. 15). A point where Agricola distances himself from Aristotle is the debate on the scope of dialectic: while Aristotle restricts dialectic to issues which have not to be determined by the particular sciences and on which there is something to be said on both sides, thus finding dialectic useful mainly for the purpose of arguing, Agricola insists that part of the role of dialectic is to teach the separate sciences how to find their materials. Agricola ascribes to dialectic the function of method for the other subjects (Mack 1993: 176). Many other more specific criticisms are directed at Aristotle, in particular in relation to the eight books of Topics. First, the scope of the considered matter is too narrow, as only the loci bound to the four predicables are tackled. Moreover, he does not describe the loci nor does he establish their number and their names and, very often, some matters are counted as loci that are not at all related to argumentation (like various prescriptions and suggestions to the arguer aiming at improving his performance at communicative and interactional level). Eventually, no indications are provided for the use of loci in the construction of arguments, so that the Aristotelian claim of providing an instrument which enables us to find proper arguments in favor and against every standpoint becomes vain (I, 3: 66-133/p. 15-17).

Now, the very hard task of implementing Aristotle's program of Topics was not fulfilled by his followers of the Peripatetic school, but by people like Cicero, who construed a list of certain and definite loci that could be universally applied. At the beginning, Cicero limited himself to listing them (in De oratore and Partitiones), then in Topica, the book entirely devoted to the loci, copiosius omnia exsecutus est (the whole matter was tackled more in detail). Unfortunately, also in homage to the jurist Trebatius, to whom the book is devoted, Cicero draws almost all examples from civil law (I, 3: 134-142/p. 17). 
Quintilian (see Winterbottom ed. 1970), whom he follows on many questions, is criticized for the indeed scarce space and care devoted to loci in the fifth book of Institutio oratoria, (I, 3: 143-147/p. 18), but he is also sharply blamed in relation to an aspect which might appear as a modest detail, but, at a closer look, shows to constitute a fundamental theoretical tenet: "Ea [tekmeria] Quintilianus inter argumenta non putat habenda, quia nihil post se dubii relinquant" (I, 21: 190-197/ pp. 112-113) (Quintilian thinks that these [undoubted clues] should not be numbered as arguments because they do not leave behind any doubt). Now, Agricola wonders how such an idea, excluding from argumentation all mathematical reasoning, which is manifestly aimed at unquestionable conclusions, could enter the mind of such an intelligent man. Our author recalls that any argumentative activity aims "ut quam minimum dubitandi relinquamus locum" (to leave open to doubt the smallest possible space). ${ }^{23}$

Themistius and Boethius are also mentioned, the former for having proposed a second list of loci, and the latter for first having simply (Boethius non aliud sane uidetur egisse) reported Cicero's and Themistius' lists and then having compared them (I, 3: 149-150/p. 18). This judgment is manifestly inadequate and unjust. In my opinion, it is motivated by the relevance ascribed by Boethius to the maxim (in his terminology locus maxima) and its differentiation from the locus differentia maximae (Stump 1978), which is properly the locus. About "people who wrote after Boethius" two remarks are made by Agricola, one of which is very questionable and not particularly relevant (they would have followed Themistius and not Boethius), while the other is profound and almost shocking: "They limited themselves to mentioning loci or to characterizing them with few words, because they considered that a deeper knowledge of loci is to be drawn from a more profound philosophical study" 24 (I, 3: 152-155/p. 18).

Particularly interesting is the conclusion of Agricola's critical overview of the state of the art: eventually, as one who was not ready to swear by the words of anybody, he had decided to each time follow the most convincing author or, in lack of a convincing author, to simply follow reason. However, he does not claim to realize anything better, he is more modestly committed to explaining the matter, maybe with less subtlety but more clarity.

\subsection{The Treatment of Loci}

\subsubsection{The Taxonomy of Loci}

The reflections by means of which our author elaborates the classification of loci and specifies the nature of each locus are often innovative and sharp. Moreover,

\footnotetext{
${ }^{23}$ On this regard, Mack (1993: 177 and ff.) remarks that, differently from Cicero, Agricola can not be defined as an Academic skeptic, since for Agricola the "certain" is included in the probabile. In support of this view, Mack cites a number of passages in the De inuentione dialectica "which show him [Agricola] treating certain arguments as part of the probabile and in which he speaks of things being true or certain".

24 "Omnes tamen satis crediderunt, locos vel nominare vel paucissimis signare, quid essent, verbis. Credo, quòd arbitrati sint, altiorem locorum notitiam ex penitiore philosophia petendam."
} 
especially in the second book, numerous fine examples are given. The criteria that are used are concisely reported in the scheme construed by the editors on the basis of chapter 4 of the first book (see Fig. 1).

In its whole, Agricola's taxonomy presents a coherent tree structure: at the highest level, internal and external loci are distinguished, the former being situated either in the constituency (substantia) of the concerned thing or around it, the latter presenting a gradually decreasing closeness to the thing.

In the thing (within or around its constituency) we find the definition and the predicables (genus, species, property), the whole and its parts and the coniugates, like wise versus wisdom, where wisdom is constitutive of the wise man not in order to be a man, but to be a wise man. Around the constituency are, in relation to a subject, those states of affairs, both static (adiacentia) and dynamic (actus), in which the subject is involved, and the subject itself.

Regarding the external loci, a strong differentiation emerges: the cognata embrace both causes (efficient and final) and outcomes (effects and destinata); the applicita comprise place, time and the connexa, which are the correlative states, i.e.

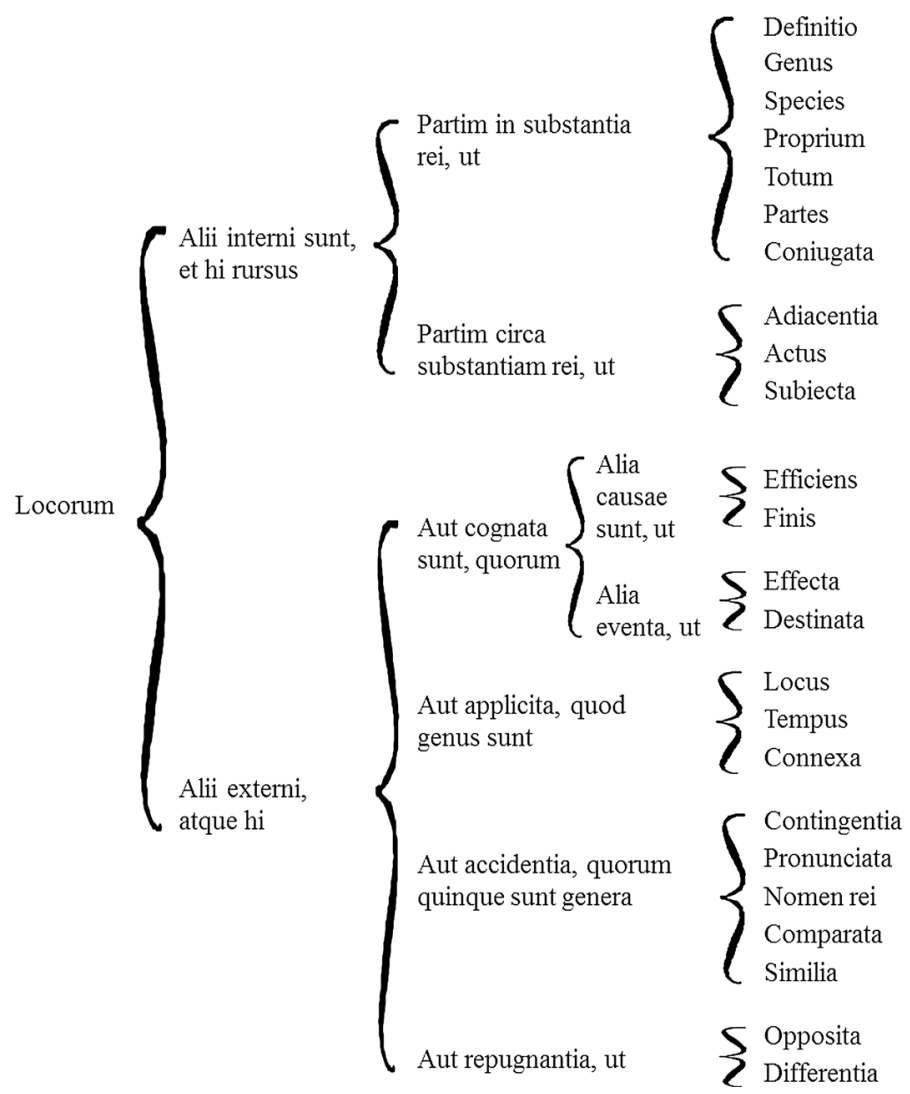

Fig. 1 Agricola's typology of loci. This schema of Agricola's typology is elaborated from a schema offered by the editors of the 1557 edition (p. 39). The original has been accurately followed, merely simplifying and rationalizing the graphics 
the states of the thing entailing the presence of another thing (like being a married or rich man, which entails the presence of a wife and of a certain wealth respectively); the accidents gather rather different non-constitutive aspects and circumstances; eventually the incompatibles (repugnantia) comprise opposites and divergents.

If we compare Agricola's taxonomy of loci with the taxonomy proposed by Boethius (see Stump ed. 1978), which was later largely confirmed and deepened by many Medieval scholars, numerous similarities but also relevant differences emerge, mainly in relation to the frontier dividing internal and external loci. Indeed, even though the most general distinction between internal and external loci is confirmed, and the maximum of closeness to the thing, i.e. to the standpoint, is identified with the loci from definition and from the whole and its parts, numerous loci, like the causes and the applicita, which were traditionally numbered among the internal ones, are moved to the other class. The criterion for the belonging to the internal loci had been identified by Buridan (Summulae de dialectica. 6.2.3, see Buridan 2001) with the fact that either the two terms constituting the habitudo of the locus denote the same reality (supponunt pro eodem) or the reality denoted by one is included in the reality denoted by the other for some mode of "being in" (in my opinion, in the sense that they belong to the same possible world). Thus, the comparison of Agricola's taxonomy to the traditional model shows that a strong and relevant justification of the fundamental dichotomy got lost. The classification of the applicita among the external loci might also be questioned, first because time and place are strictly constitutive of situations (adiacentia) and events (actus), which are consistently numbered among the internal loci, and secondly because the correlatives (connexa), like king versus kingdom or husband versus wife (where the first term imposes a coexistence condition on the second) prove to equally pertain to the internal loci.

However, despite some inconsistencies and a certain theoretical impoverishment, apparently due to the negligence of the relevant contributions provided by Medieval scholars, Agricola's taxonomy constitutes a real advancement, regarding the identification and justification of the single loci and the innovative categories adopted in the construction of the major classes.

\subsubsection{Definitions Towards Ontologies}

Let us now consider some of the fine analyses elaborated by Agricola for loci. His treatment of definition (I, 5) is rigorous and innovative; definition is first distinguished from description, because its purpose is to say what the thing is and not how it is. Agricola confirms the validity of the classical Aristotelian procedure for defining, which connects the next genus (genus proximum) with the specific difference. However, he also remarks that perfectly fitting definitions, like Homo est animal rationale, where rationale really identifies the constitutive trait characterizing humans among all other animals, are not available for non-humans. For all other non-human species, which are called bruta in Latin, like donkeys, mules and horses, no specific difference in form of one predicate is available. Here, a conjunction of predicates like auritus (long-eared), solidis pedibus (single toed) and foecundus (fertile) plays the role of specific difference, as it enables us to 
differentiate the nature of donkeys from all other animals: single toed are only donkeys, horses and mules, but horses are not long-eared and mules are not fertile. Consequently: "itaque tandem velut gradibus quibusdam ad id quod definitum est peruenitur" (I, 5: 41-43/p. 27) (eventually, we arrive, by climbing a kind of steps, at the defined). Not simply connecting genus with specific difference, but conjoining often complex sets of predicates (see complexus definitionis, I, 5: 74-75/p. 27) is necessary in order to define many entities and states of affairs. This way, definition procedures get very close to the ontologies ${ }^{25}$ elaborated in current trends of semantics.

Agricola also stresses the rhetorical usefulness to the arguer of designing such definitions/ontologies, not only in order to know the things, "which, having been made explicit by means of the definition, suggest to the mind-it is strange how it happens - some precise orientations regarding the thoughts that should be unfolded, but also to enhance the arguer's authority" ${ }^{26}$ (I, 5: 109-103/p. 28-29). The author proposes two fair examples, by defining as many social realities: ius (law) and ciuitas (political community). In both cases the definition is the result of intense considerations through which the distinctive function of each predicate of the definition is justified.

More in detail, a conceptual basis constituting the genus is enriched (specified) step by step, by adding all traits that prove to be needed in order to differentiate the concerned domain from all other domains. I simply report the conclusion of the second definition procedure: "Dicemus itaque ciuitatem esse multitudinem collectam, ad statum rerum suarum tuendum per se sufficientem, quae consensu sit legum uitaeque conniuncta" (I, 5: 96-98/p. 28) (Therefore we shall say that a ciuitas is a multitude of people gathered together, in itself sufficient to the defense of its goods, and that is kept together by the communal acceptance of laws and ways of life).

\subsubsection{Analysis of the Domain of Events and Actions}

In general, Agricola's taxonomy seems to upset the system of Aristotelian categories. The loci circa substantiam (around the substance) embrace the categories of quality and quantity under the unique label of adiacentia (covering the static states of affairs) (I, 11), while the categories of action and passion are subsumed under the wider category of events or dynamic states of affairs ("Quod igitur proprie actus est, id oportet ut sit in quadam agitatione .. positum", I, 12:

\footnotetext{
25 The term ontology refers, especially in Aristotelian philosophical tradition, to the doctrine of being. Thus the traditional philosophical concept of ontology is mainly meant to deal with questions concerning what entities exist or at what conditions they can be said to exist, by what relations they are bound together and how they can be grouped and related within a hierarchy, and subdivided according to similarities and differences. More recently, within computer science and information science, the term ontology has been used for referring to a formal representation of a set of concepts within a domain and the relationships between those concepts, that may be used to define the domain and to reason about its (constitutive) properties. In my opinion, while, in general, loci are situated by Agricola in the domain defined by the first notion of ontology, Agricola's understanding of definition is close to this second notion of ontology.

26 "Utilis est haec definiendi ratio, cum propter rerum cognitionem, quae definitione explicatae, mirum est quo pacto uelut certum quoddam signum destinandarum cogitationum proponant animo: tum quod parat autoritatem disserenti."
} 
62-63/p. 72), which are named actus (I, 12) and the locus of subject comes to coincide with the substance in which both static and dynamic states of affairs are inherent (I, 13). Within the locus of events (actus), action (actio) is specified as a purposeful behavior, (I, 4: 45/p. 23 and I, c.12: 42-44/p. 71: "finem aliquem respicit"). Interestingly, the author makes a distinction between the purpose and the effect of an action and gives a fine example to highlight it (I, 4: 55-58/p. 23): shoes are the effect of shoemaker's action, while protection of feet is its purpose.

\subsection{Argumentation Versus Exposition}

In the 16th chapter of the second book, Agricola brings to light that loci, as headings of the semantic network shaping the map of reality, do not exhaust their role in the construction of arguments (see also Mack 1993), as they are not less relevant in expositio, i.e. in the presentation of reality. The role played in exposition is particularly important for two main reasons: it stresses the ontological nature of loci, as it is properly understood by Agricola, and specifies the differences, without neglecting the connections, between explanation and argumentation.

Loci are not exclusively argumentative categories. They are the nodes of the ontological structure of reality and are used in its representation for describing it, explaining it and arguing for it and from it.

Moreover, considering, in particular, causal exposition or explanation, Agricola discovers that the same state of affairs can be referred to both in explanatory and in argumentative terms. A renowned passage of Virgil's Aeneid (II, 16: 27/p. 258-259) is mentioned (Urbs antiqua fuit, Tyrii tenuere coloni, Karthago ... Aeneid I Book, vv. 12-80, see Colombo ed. 1967), in which the poet recollects the causes why Juno hated Aeneas. In a different communicative situation, in which Juno's hate against Aeneas might be doubted (thus becoming a standpoint), the discourse would be transformed into an argumentation and the causal relations used by Virgil in order to explain Juno's hostile feeling would be used as arguments to prove the truth of this feeling. Another interesting example refers to the eclipse of the moon (II, 16: 43-53/p. 259). Let us consider the interposition of the earth between the sun and the moon. One can explain the eclipse of the moon as the effect of such an interposition, but the evidence of this particular position of the earth could, in another communicative interaction, also be interpreted as an argument allowing to predict an eclipse of the moon.

\subsection{Emotions, Arrangement and Other Presentational Techniques}

The third book concisely elaborates on numerous presentational techniques aimed at the effectiveness of argumentation and investigates how audience can be influenced by exciting and orienting its feelings and can be entertained and even delighted by inducing in it a benevolent and careful attitude and, eventually, what arrangement (dispositio) of issues, partes orationis and arguments should be preferred in different argumentative situations and in different types of discourse.

Emotion (Latin affectus, "modification of mind") is defined as an impetus or impulse by which we are driven with more vehemence, compared with a quiet mood 
of mind, to pursue and to escape expedient and harmful things respectively. More in detail, inasmuch as they inhere to possible events, good and evil cause attraction or repulsion respectively; instead, inasmuch as they characterize real facts, they engender a joyful reaction or sorrow depending on whether such facts involve people who deserve or people who do not deserve to be involved in them-where, by definition, the arguer merits to be affected only by nice things-(III, 1-4).

Loci are once again invoked to specify the nature of emotions, in particular to distinguish the role of subject (see above Sect. 4.2.1) as the person affected by the event and of efficient cause as the person bringing about the event. In connection with this distinction two fundamental emotions are explained: mercy arises toward the person who is victim of an unjust, undue harm, while hate is excited against the person who has caused it. The generation of emotions in the discourse (oratio) can take a threefold form: they can be simulated or indeed experienced by the speaker; they can be represented as experienced by the people the discourse refers to; or they can be excited in the audience by the discourse (III, 2). All in all, Agricola's treatment of feelings is very concise: the readers are invited to recur for a more comprehensive treatment to Aristotle's Rhetoric and to mainly exploit their sensus communis in connecting the nature of the event with the audience's attitudes (III, 1: $67-71 /$ p. 380). As in the generation of emotions appearance is somehow more important than reality, presentational techniques show to play an emergent role. For instance, the emotional effect produced by evoking the scenery of war is far stronger if war is not simply mentioned by the noun, but it is vividly rendered by listing a number of its harmful effects (metus hostiles, praedae incendiaque uillarum, expugnationes oppidorum, expensas militares ...) (III, 3: 52-60/p. 388).

Strategies triggering emotional effectiveness, as well as other procedures aimed at defining the size of the discourse by unfolding or narrowing its design, which properly pertain to elocutionary rhetoric, are given only a very concise treatment and the reader is referred to the larger presentations offered by Aristotle, Cicero and Quintilian. More attention is paid (III, 8-16) to the strategies of arrangement (dispositio), which in Antiquity had received only a cursory consideration.

Indeed, this subject is shortly hinted in the eighth Book of Aristotle's Topics. Not much more space is devoted to it by Quintilian, who in the seventh Book of his treatise (see Winterbottom ed. 1970), after having denied the existence of any general rule regarding the art of disposition (nullis perpetuis legibus statui credidit posse: III, 8: 18-19/p. 413), suggests that decisions on these matters can be taken only in strict connection with the concrete situation. Agricola is instead convinced that, not differently from invention, some systematic approach should be identified for disposition too.

Agricola's elaboration of the subject moves from the distinction of the different principles disposition is concerned with, namely the natural, the arbitrary and the artificial orders. The natural order is the order inhering to the matter itself (the referent of the discourse); the arbitrary order coincides with the absence of any natural order or with the negligence of the existing natural order by the speaker, who, in both cases, adopts in the discourse the disposition that is suggested by the opportunities of concatenation that are offered by the ongoing discourse, (utcumque alia [sc. res] alii aptissime ex dicendi occasione subtexi potest, proinde 
subiungitur); the artificial order occurs when, the natural order is twisted on purpose and the order adopted in the discourse only depends on principles governing the construction of the discourse itself (III, 8: 38-55/pp. 413-414).

Particularly in relation to argumentative discourses, the natural order proves to be relevant. Four dimensions of the referent are distinguished and as many subtypes of order are singled out: (1) the temporal sequence of events; (2) the semantic-logical implications between the constituents of the same state of affairs, in the sense that, ontologically, the presupposed precedes the presupposing (the substance precedes in this dimension the accident because it is presupposed by the accident) and, from another perspective, what is known precedes the unknown; (3) the order deriving from the perspective adopted in relation to different reference points; (4) the order following the adopted hierarchies of dignity and value ${ }^{27}$ (III, 8: 56-86/p. 414).

The genre to which the discourse belongs influences the choice of the type and the subtype of order (III, 9: 3-5/p. 416 and ff.). For instance, if they are historical, the discourses in which exposition of events dominates privilege the naturaltemporal order, while, if they are poetic, they usually recur to different strategies of artificial order. In the first case an effect of trustworthiness (of adherence to reality) is created, while other, different, values are pursued by the poet through artificial orders.

In the fifteenth chapter of the third book, Agricola collects several pieces of advice that should be carefully observed throughout the argumentative interaction (cautiones aliquot inter argumentandum diligenter observandae). These pieces of advice are centered on a caveat that is very close to an analogous recommendation of Aristotle in the eighth Book of his Topics (Ross 1958): if there is something on which a major aspect of the issue depends, this should be promptly delivered to the audience as a "deposit", (in antecessum) and in every case before facing the point we want to achieve by it and as if doing something else (III, 15: 8-12/p. 446). In relation to this principle, a number of strategies facilitating the conquest of the audience's consent are illustrated. The persuasion process is presented like a multiattack strategy aimed at weakening the audience's resistance both by masking one's own intention (i. e. the standpoint) and by identifying and anticipating those premises that are easily accepted by the audience. In both cases indirect strategies are preferred to an explicit and direct confrontation, so that the treatment of the intended topic is postponed until all necessary premises are secured, and thus, eventually, the audience feels accepting something that they already believed. Moreover, the arguers should in all possible ways protect and promote their argumentative reputation, especially by starting their speech with a strong and effective argumentative move.

The sixteenth and last chapter of the third Book is devoted to the practices facilitating the acquisition and enhancement of argumentative and rhetorical skills. Without denying the complexity and even the extreme difficulty of such a competence, mainly in relation to the recurrent necessity of extemporary public interventions about unfamiliar issues, the author maintains that the acquisition of

\footnotetext{
27 Mack (1993: 219-220) signals Aristotle's Categories (14a26-14b9) as a plausible source for this treatment.
} 
this competence is never impossible: "the power of human mind is in fact enormous, immense, unbelievable, so that for it almost nothing is difficult except what it does not want" (III, 16: 117-118/p. 454). (Ingens enim, immensa, incredibilis est uis mentis humanae, et cui nihil propemodum difficile sit nisi quod non uult). I find that the examples brought by Agricola to illustrate the extraordinary power of human mind are particularly felicitous and even surprising, like the case of a person who, though being deaf and therefore dumb since the first years of his life, however learned to understand every written text and to express by writing all his own thoughts. In relation to the recovering of another perceptive disability Agricola mentions blind people who proved to be able to walk through the network of the town streets without losing their way, and to reach their home door. But the ability of many musicians to improvise musical texts never encountered before is not less surprising for Agricola. Analogously, he attributes to the human mind the potential to reach an almost automatic mastery of argumentative strategies.

\section{Conclusive Remarks}

Both innovation and continuity characterize Agricola's contribution to the study of argumentation. While breaking with the Medieval tradition and adopting in relation to it a rather polemical attitude, he established a critical continuity with Antiquity. Numerous innovative aspects emerge in his doctrine: his autonomous, correctly critical, attitude towards the authorities of tradition, his original classification and definition of loci, the often sharp and fertile insights through which the nature of each locus is highlighted, the richness of examples, the discovery of the relevant role played by loci in exposition.

Indeed, despite a certain theoretical impoverishment, which is bound to the removal of maxims, partly depending, in my opinion, on the negligence of the relevant contributions provided by Medieval scholars, Agricola's taxonomy represents a substantial advancement, both regarding the identification and justification of the single loci and the innovative categories adopted in the construction of the major classes. Moreover, thanks to the discovery of the relevant role played by them not only in argumentation but also in exposition, loci are no longer exclusively argumentative categories. They become, in this new perspective, the nodes of the ontological structure of reality that are available, in the construction of human discourse, for the representation of reality aiming at describing it, explaining it and arguing for it and from it.

Agricola's work on dialectical invention really represents an important contribution to the development of rhetoric and argumentation theory. However, Agricola's work does not only represent an important chapter in the history of our discipline: for numerous topics it deserves to be considered in the current scientific debate.

This holds in particular for the still controversial problem of argument schemes that may be regarded as the present day heirs of loci. Evermore, Agricola's position represents in relation to argument schemes a very audacious challenge: by extending the relevance of loci beyond argumentation to descriptive and explanatory discours, 
he linked loci to the meta-categorial level ${ }^{28}$ of rhetorical relations (also called connective predicates) on which discursive congruity mainly depends (Rigotti 2005; Rocci 2005; Rigotti and Rocci 2006). Eventually, he is our legitimate interlocutor also in relation to the concept of strategic maneuvering (van Eemeren 2010), in particular for the invention and selection of arguments, for the arrangement of arguments and other presentational devices. The rhetorical dimension is often predominant in his approach. However, the critical remark moved to Quintilian and numerous passages in which the validity of arguments is considered also prove his strong commitment to dialectical cogency.

\section{References}

Agricola Rodolphus. 1539. Rodolphi Agricolae Phrisii de inuentione dialectica libri omnes et integri et recogniti, qui iam olim quidem in publicum prodierunt, sed trunci ac mutili nec minus item deprauati, nunc demum ad autographi exemplaris fidem per Alardum Aemstelredamum accuratius emendati, et additis annotationibus illustrati (...). Coloniae Ioannes Gymnicus excudebat Anno a Christo nato M. D. XXXIX.

Agricola Rodolphus. 1557. Rodolphi Agricolae Phrisii de inuentione dialectica libri omnes integri et recogniti iuxta autographi, nuper D. Alardi Aemstelredami opera in lucem educti fidem, atque doctissimis scholiis illustrati, Ioannis Phrissem, Alardi Aemstelredami, Reinardi Hadamarii. Quorum scholia exactissimo iudicio contulit ac congessit Ioannes Nouiomagus. Coloniae Anno M. D. LVII.

Akkerman, F. (ed.). 2012. Rudolph Agricola: Six lives and Erasmus's Testimonies. Assen: Koninklijke van Gorcum.

Boethius, A.M.S. De differentiis topicis: Patrologia Latina 1173B-1216D. http://individual.utoronto.ca/ pking/resources/boethius/De_differentiis_topicis.txt.

Braet, A. 2005. The common topic in Aristotle's Rhetoric: Precursor of the argumentation scheme. Argumentation 19: 65-83.

Bochenski, M. (ed.). 1947. Petri Hispani Summulae Logicales. Torino: Marietti.

Buridan, J. 2001. Summulae de Dialectica, an annotated translation with a philosophical introduction by G. Klima. New Haven: Yale University Press.

Colombo, S. (ed.). 1967. P. Vergilii Maronis Opera. Torino: SEI.

De Rijk, L.M. (ed.). 1970. Petrus Abaelardus, Dialectica: First complete edition of the Parisian manuscript. Assen: Van Gorcum.

Gilson, Ė.-H. 1952. Jean Duns Scot. Introduction à ses positions fondamentales. Paris: J. Vrin.

Green-Pedersen, N.J. 1987. The topics in medieval logic. Argumentation 1: 407-417.

Mack, P. 1993. Renaissance argument: Valla and Agricola in the traditions of Rhetoric and Dialectic. Leiden/New York/Köln: Brill.

Mundt, L. (ed.). 1992. Rudolph Agricola, De inventione dialectica libri tres. Drei Bücher über die Inventio Dialectica. Auf der Grundlage der Edition von Alardus von Amsterdam (1539). kritisch herausgegeben, übersetzt und kommentiert. Tübingen.

Nauta, L. 2012. From universals to topics: The realism of Rudolf Agricola, with an edition of his reply to a critic. Vivarium 50: 190-224.

Reinhardt, T. (ed.). 2003. Marcus Tullius Cicero, Topica. Oxford: Oxford University Press.

Rigotti, E. 2005. Congruity Theory and Argumentation. In Argumentation in dialogic interaction. Special Issue of Studies in Communication Sciences, ed. M. Dascal, F. H. van Eemeren, E. Rigotti, S. Stati and A. Rocci, 75-96.

\footnotetext{
${ }^{28}$ By declaredly neglecting the medieval contribution to topics, Agricola also fails to seize the homogeneity of his notion of loci and the important semantic notion of intentiones secundae. GreenPedersen $(1987,413)$ even suggests "that the reflections on the status and function of the loci have been instrumental in the elaboration of this doctrine", namely of the doctrine of intentiones secundae.
} 
Rocci, A. 2005. Connective predicates in monologic and dialogic argumentation. In Argumentation in dialogic interaction. Special Issue of Studies in Communication Sciences, ed. M. Dascal, F. H. van Eemeren, E. Rigotti, S. Stati and A. Rocci, 97-118.

Rigotti, E. 2008. Locus a causa finali. In Proceedings of the IADA Workshop Word meaning in argumentative dialogue. Homage to Sorin Stati, Special issue of L'analisi linguistica e letteraria XVI 2, ed. G. Gobber, S. Cantarini, S. Cigada, M. C. Gatti and S. Gilardoni, 559-576.

Rigotti, E., and S. Greco Morasso. 2010. Comparing the argumentum model of topics to other contemporary approaches to argument schemes: The procedural and material components. Argumentation 24: 489-512.

Rigotti, E., and A. Rocci. 2006. Tema-rema e connettivo: la congruità semantico-pragmatica del testo. In Syndesmoi: connettivi nella realtà dei testi, ed. G. Gobber, M.C. Gatti, and S. Cigada, 3-44. Milano: Vita e Pensiero.

Ross, W.D. (ed.). 1958. Aristotelis Topica et Sophistici Elenchi. Oxford: Oxford University Press.

Stump, E. (ed.). 1978. Boethius's “De topicis differentiis”. Ithaca (NY): Cornell University Press.

van Eemeren, F.H. 2010. Strategic maneuvering in argumentative discourse. Amsterdam/Philadelphia: John Benjamins.

van Eemeren, F.H., and P. Houtlosser. 2002. Strategic maneuvering in argumentative discourse: Maintaining a delicate balance. In Dialectic and Rhetoric: The warp and woof of argumentation analysis, ed. F.H. van Eemeren, and P. Houtlosser, 131-159. Dortrech: Kluwer Academic.

Vasoli, C. 1968. La dialettica e la retorica dell'Umanesimo. "Invenzione" e "Metodo" nella cultura del XV e XVI secolo. Milano: Feltrinelli.

Winterbottom, M. (ed.). 1970. M. Fabi Quintiliani Institutionis oratoriae libri duodecim. Oxford: Oxford University Press. 